\title{
PENAFSIRAN RIBA \\ Studi Komparatif Antara Kaum Modernis dan Neo-Revivalis
}

\author{
Oleh: \\ A. Taufiq Buhari ${ }^{1}$ \\ Email: taufiqbuhari@gmail.com
}

\begin{abstract}
Interpretation of interest as applied to modern banking today, there are still differing views. Modernists view the prohibition of usury as being understood by emphasizing the rational aspect. Through this understanding, the element of injustice becomes a central issue for its prohibition. They seem to tolerate if their savings are based on the mudharabah system, because they can be found on the basis of their legitimacy. In addition, it is permissible if really forced (dharuri) or really needs (hajat). Also allows productive loan interest while consumptive loan interest is not allowed. While the Neo Revivalists were of the view that the prohibition of usury was understood legally formally as conceptualized in Islamic law. This view emphasizes the legal form of usury as expressed in Islamic law. They assert that the statement set out in the Qur'an must take its literal meaning, regardless of what was practiced in the pre-Islamic period. Whatever the circumstances, the lender does not have the right to receive additions to and exceed the principal
\end{abstract}

Key words: usury, comparative, Modernist, Neo-Revivalist

\section{Pendahuluan}

Kebanyakan sarjana muslim modern berbeda pandangan dalam menilai apakah bunga sebagaimana diaplikasikan perbankan modern saat ini, termasuk seperti yang dilarang dalam al-Qur'an atau al-Hadits. Perbedaan itu tampaknya selalu mengarah pada dua aspek permasalahan sentral. Pertama, larangan riba dipahami dengan menekankan pada aspek rasional. Melalui pemahaman ini, unsur ketidakadilan menjadi isu sentral

${ }^{1}$ Dosen Prodi Ekonomi Syariah STAI Syaichona Moh. Cholil Bangkalan 
atas pelarangannya. Kedua larangan riba dipahami secara legal formal sebagaimana dikonseptualisasikan dalam hukum Islam.

Dalam konteks ini, Abdullah Saed mengangkat dua model pandangan yang dirasa bisa mewakili khazanah pemikiran para ulama' seputar penafsiraanya terhadap riba sebagaimana yang terungkapkan dalam al-Qur'an ataupun al-Hadits. Dua pandangan ini disimpulkan sebagai pandangan kaum Modernis dan kaum Neo-Revivalis.

Para kaum Modernis cenderung pada pandangan yang pertama, sementara kaum Neo-Revivalis condong pada pandangan yang kedua.

\section{Pandangan Kaum Modernis Tentang Riba dan Bunga}

Para kaum Modernis seperti Fazur Rahman (1964), Muhammad Asad (1984), Said al-Hajjar (1989) dan Abdul Mu'in al-Namir (1989) menekankan perhatian pada aspek moral sebagai bentuk pelarangan riba, dan terkesan mengenyampingkan aspek legal formal sebagaimana yang dijelaskan dalam hukum Islam. Menurut mereka, dilarangnya riba itu karena menimbulkan ketidakadilan, sebagaimana yang diungkapkan di dalam alQur'an "kamu tidak menganiaya dan tidak pula kamu teraniaya". Kaum Modernis juga mendasarkan pandangan mereka terhadap pandangan ulama' klasik seperti: Razi, Ibnu Qayyim dan Ibnu Taimiyah. Razi dalam menjelaskan tentang sebab-sebab larangan riba menyatakan bahwa pemberi pinjaman itu akan semakin kaya, sementara penerima pinjaman akan semakin miskin. Karenanya ia tidak membolehkan transaksi yang mengundang unsur riba, termasuk membuka jalan bagi si kaya melakukan pemerasan bagi si miskin. ${ }^{2}$ Sementara menurut Ibnu Qayyim larangan riba itu berkaitan dengan aspek moral. Ia mendasarkan pada praktik riba pada masa pra-Islam, dimana para peminjam saat itu kebanyakan adalah orang miskin yang tidak punya pilihan lagi kecuali menangguhkan pembayaran hutangnya. ${ }^{3}$

Muhammad Assad seorang mufassir modern mengatakan secara kasarnya dapat dikatakan bahwa kekejaman riba sebagaimana yang di

\footnotetext{
${ }^{2}$ Al-Imam al-Fahr al-Razi, al-Tafsir al-Kabir Juz iV (Kairo: al-Matba'a al-bahiya, 1983), 94.

${ }^{3}$ Ibn al-Qayyim al-Jauziyyah, A'lam al-Muwaqqi' in 'an Rabb al-Alamin II (Dar al-Jil. tt),
} 157. 
ungkapkan dalam al-Qur'an ataupun al-Hadits adalah terletak pada adanya keuntungan yang diperoleh melalui pembebanan (tangguhan) bunga pinjaman yang mencerminkan tindakan eksploitasi terhadap pihak yang lemah melalui kekuatan dan kelicikan. Karena itulah transaksi yang dilarang karena termasuk katagori riba adalah transaksi yang tujuan akhirnya mencerminkan suatu tindakan yang amoral. ${ }^{4}$

Sementara Fazlur Rahman dalam menanggapi sikap mayoritas kalangan muslim terhadap bunga mengatakan mayoritas kaum muslim yang bermaksud baik dengan sangat bijaksana berpegang teguh pada keimannanya, menyatakan bahwa al-Qur'an melarang seluruh bunga. Saya merasa sedih karena karena pemahaman mereka didapat dengan cara mengabaikan bentuk yang sebagaimana menurut sejarah itu dilarang, sehingga al-Qur'an mencelanya sebagai perbuatan keji dan kejam, serta menganggapnya sebagai tindakan eksploitasi. ${ }^{5}$

Selanjutnya beberapa keterangan dan argumen dari para Modernis seputar persoalan yang berkaitan dengan riba antara lain:

1. Karakteristik riba yang dilarang pada masa pra-Islam

Muhammad Abduh (w.1905) dan juga muridnya Muhammad Rashid Ridha, menjelaskan bahwa bentuk riba yang dilarang pada masa praIslam adalah riba yang dipraktikkan dalam bentuk tambahan pembayaran yang diminta dari pinjaman yang telah melewati batas tempo pembayaran. ${ }^{6}$ Namun demikian baik Abduh maupun Ridha tidak memberi keterangan yang jelas tentang bunga (interest) yang diberikan kepada uang simpanan para penabung. Mereka kelihatan mentolerir jika tabungannya berdasarkan sistem mudharabah, karena menurut dasar ini bisa ditemukan dasar legitimasinya.

Sementara Abdurrazaq Samhuri menegaskan bahwa bunga yang dilarang adalah yang berlipat ganda. Hal ini didasarkan pada bukti faktual pada praktik riba pada masa pra-Islam dan juga implikasi yang ditimbulkanya. Argumentasi ini juga dikemukakan oleh Ibrahim Zakial-

\footnotetext{
${ }^{4}$ Muhammad Assad, The Massage of The Qur'an (Gibraltar: Dar-Andalus, 1984), 633.

${ }^{5}$ Fazlur Rahman, Islamic: Challenges and Opportunities (Eidenburgh: Eidenburgh University Press, 1997), 326.

${ }^{6}$ Nabil A. Salih, Unlufun Gain and Legitimate Profil in Islamic Low (Cambridge: Cambridge University Press, 1986), 29.
} 
Baidowi (pakar hukum Mesir). Menurutnya, larangan keras praktik riba pada masa pra-Islam adalah adanya peningkatan dari nilai pokok, ketika pinjaman tidak dapat mengembalikan hutangnya, justru ia harus menerima pinjaman baru, begitu seterusnya. ${ }^{7}$

2. Keterpaksaan menyebabkan kebolehan bunga yang tidak berlipat ganda Samhuri menegaskan bahwa larangan riba dalam semua bentuknya bermuara pada aspek norma, meskipun tingkan larangannya bervariasi. Berdasarkan alasan ini, riba tidak dapat dianggap sah menurut hukum kecuali benar-benar dalam keadaan terpaksa (dharuri) atau benar-benar butuh (hajat). Menurutnya riba jahiliyah adalah riba yang paling buruk di antara sekian bentuk riba, oleh karena itu dilarang secara mutlak. Kadarnya sama pada saat ini jika kita meminta bunga secara berlipat ganda. Faktor terpaksa tidak berlaku bagi pemberi pinjaman. Waktu peminjam terpaksa meminjam berdasarkan tingkat bunga yang tidak wajar, dimana letak keterpaksaan kreditur ketika membebani bunga secara berlipat ganda? Tanya Samhuri.

3. Dalam kasus bunga pinjman ia berpendapat: dalam sistem ekonomi kapitalis modal dikuasai oleh individu, lembaga dan bank, bukan dikuasai oleh pemerintah. Para penguasa umumnya membutuhkan modal untuk investasi. Selama modal tidak dikuasai oleh pemerintah dan kebutuhan untuk memperoleh modal melalui pinjaman yang tingkat suku bunganya sudah ditentukan, adalah sah menurut hukum, sebagai bentuk pengecualian dari larangannya. Seseorang yang mempunyai modal dan dia mengalokasikan modalnya ke dalam pekerjaan dan perusahaannya, maka dia sewajarnya memiliki kewajiban dan hak yang dikerjakannya tidak menyimpang dari ketidakadilan baik pada orang lain maupun pada dirinya. Tingkat bunga yang tidak berlipat ganda dihukumi sebagi suatu yang sah menurut hukum apabila memang terdesak oleh kebutuhan (hajat). Samhuri selanjutnya mengatakan bahwa hukum itu seharusnya meentukan spesifikasi yang memuat tentang batasan-batasan tingkat bunga, cara pembayaran, serta

${ }^{7}$ Chibli Mallat, The Debate On Riba and interest in twentieth Century Jurisprudence (London: Graham \& Trotman, 1998), 80. 
seluruh bunga yang dibayarkan supaya dalam setiap kasus khusus dapat diperkirakan batasan-batasan kebolehan menurut hukum. ${ }^{8}$

4. Pinjaman konsumtif atau pinjaman produktif

Doualibi, seorang politisi kontemporer Syria membedakan antara pinjaman produktif dengan pinjaman konsumtif. Ia mengatakan bahwa bunga pinjaman produktif adalah boleh sedangkan bunga pinjaman konsumtif tidak diperbolehkan. Pernyataan ini didasarkan pada penjelasan al-Qur'an tentang masalah riba. Menurutnya permasalah riba di dalam al-Qur'an itu terkait dengan konteks meringankan penderitaan para fakir, miskin, masyarakat lemah, dan pihak yang terbelenggu oleh beban utang dan tidak mampu melepaskan dirinya. Atas dasar pertimbangan tersebut, maka pelarangan riba dalam konteks al-Qur'an itu berkaitan dengan pinjaman konsumtif. ${ }^{9}$

5. Individual atau institusional

Larangan riba itu lebih mengarah pada individual saja. Sedangkan pemberian atau pengambilan bunga bagi badan hukum, seperti perusahaan, bank dan pemerintah tidak termasuk riba. Pandangan ini juga menjelaskan bahwa penerimaa bunga oleh individu dari badan hukum seperti bank tidak termasuk riba, sebab seorang individu tidak dapat mengeksploitasi sebuah organisasi yang lebih besar seperti bank. Dewan Agama Pakistan pada tahun 1964 juga masih ragu dalam menetapkan bahwa pinjaman institusioal itu juga termasuk riba.

Dewan Penasehat Agama juga setuju bahwa riba adalah dilarang, tetapi tidak ada kesepakatan di antara mereka mengenai bunga (interest) sebagaimaa yang tanpak dalam berbagai bentuk transakti yang berlaku di masyarakat, termasuk kredit institusional, apakah termasuk spesifikasi riba sebagaimana yang tercantum di dalam al-Qur'an.

6. Bunga nominal atau real

Ditegaskan bahwa di dalam sebuah ekonomi inflasioner, rata-rata bunga juga dipungut untuk mengoreksi kerugian kreditur yang disebabkan inflasi. Hal ini bisa dibenarkan dengan cara indeksasi pinjaman, yaitu

${ }^{8}$ Abd. Al-Razzaq al-Sanhuri, Masadir al-Haqq fi Fiqh al-Islam (Bairut: al-Majma' al-Arab al-Islam, 1967), 242-244.

${ }^{9}$ Muhammad Abu Zahra, Buhuth fi al-Riba (Kuwait: Dar al-Buhuth al-'Ilmiya, 1970), 52-57. 
dengan memperbolehkan tambahan (an interes) untuk dijadikan kompensasi bagi kerugian dari kekuatan uang. Untuk mendukung argumen ini, para pemrakarsa pandangan ini seperti Syauqi Dunya (1985), mengajukan beberapa pandangan yang berkaitan dengan pembahasan mereka tentang kontrak-kontrak pinjaman.

Seperti yang dibahas dalam kitab fikih, hutang dalam pinjaman bisa berupa barang atau uang, jika pinjaman itu berupa barang, biasanya para ahli hukum mengemukakan pandangannya bahwa debitur harus membayar kembali dengan barang yang sama (1 kg daging dengan $1 \mathrm{~kg}$ daging ) sejauh terdapat barang yang sama. Sebaliknya jika nilainya tidak berubah sejak kontrak pinjaman dimasukkan, maka nilainya disesuaikan. Perbedaan pendapat muncul sejak nilai barang berubah, jika perubahan nilai barang akibat kerusakan barang itu, maka para ahli mengambil pandangan nilai awal dari barang itu yang harus dikembalikan. Jika perubahan nilai itu disebabkan perubahan tempat, maka pandangan mayoritas ahli hukum nilai dari barang obyek hutang ketika hutang terjadi yang dibayarkan, dan bukan dengan barang yang sama (setelah rusak). Jika perubahan itu disebabkan oleh waktu, yaitu akibat dari perubahan harga, beberapa ulama' ada yang mengatakan harus dibayar dengan barang yang sama, sementara yang lain bahwa seharusnya dibayar dengan nilai awal barang tersebut.10

Ketika hutang berupa uang dan nilainya berubah, beberapa ahli hukum berpandangan bahwa meskipun nilainya berubah, kreditur harus menerima jumlah awal dari pembayaran hutang. Ahli hukum Hanafiyah secara umum, dan seorang sarjana ulung dari Hambaliyah yaitu Ibnu Taimiyah memandang bahwa nilai uang ketika terjadi hutang itulah yang harus dibayarkan. Pandangan-pandangan ini mengarahkan pada kesimpulan bahwa tidak ada kesepakatan mengenai isu ini, apakah dalam situasi inflasi atau deflasi, nilai uang yang sama harus dibayar dalam pembayaran hutang.

Seseorang sarjana Pakistan, Quraisy, meringkas argumentasi ini dengan mengatakan: menurut prinsip-prinsip keuangan tentang uang yang

${ }^{10}$ Shawqi Dunya, Taqallubat al-Quwwat al-Shar'iyya li al-Nuqud (Kairo: al-Bunuk alIskamiyah, 1985), 39-45. 
sama harus dikembalikan kepada yang sama dan setiap ekses dari jumlah pinjaman akan didefinisikan sebagai riba. Dalam kasus modal fisik atau logam, atau komoditas seperti emas, pengembalian terhadap pinjaman dengan ketat sesuai dengan bentuk dan subtansi dari modal yang dipinjam. Diterjemahkan dari istilah-istilah uang kertas dan transaksi keuangan modern, syarat mempertahankan bentuk dan subtansi dari modal bisa dipuaskan dengan mengambilkan pinjaman dalam pengertian kekuatan membeli dari jumlah pinjaman awal.

Demikian juga pendapat Khalid Nuhammad Ishaque, seorang sarjana Pakistan juga mengatakan al-Qur'an memerintahkan bahwa simpanan (kekayaan) yang tidak digunakan harus disediakan untuk digunakan oleh yang lain, dan untungnya tidak diinginkan oleh pemilik kekayaan jika ia sendiri tidak menggunakannya. Oleh karena itu sepanjang dijamin bahwa seseorang yang menyimpan akan memperoleh kembali apa yang dia simpan (dan bukan uang kertas dari nilai denominasinya yang sama dengan kekuatan membeli yang mengalami penurunan), dia tidak punya alasan untuk komplain, jika uang itu menjadi subyek inflasi dan deflasi, maka pihak-pihak itu memberikan keuntungan dengan nilai yang konsisten, yaitu nilai dari kekuatan membeli (jika itu pinjaman uang) ketika pinjaman itu dilakukan. ${ }^{11}$

\section{Pandangan Kaum Neo-Revivalis Tentang Riba dan Bunga}

Pandangan mereka adalah sesuatu yang dominan dalam perdebatan kontemporer. Pandangan ini menekankan bentuk legal dari riba sebagaimana yang diungkapkan dalam hukum Islam. Mereka menegaskan bahwa pernyataan yang ditetapkan dalam al-Qur'an harus diambil makna harfiahnya, tanpa memperhatikan apa yang dipraktikkan dalam periode pra-Islam. Menurut pandangan ini karena al-Qur'an telah menyatakan bahwa hanya uang pokok yang diambil, maka tidak ada pilihan lain kecuali menafsirkan riba sesuai dengan pernyataan itu. Oleh karena itu, keberadaan ketidakadilan atau sebaliknya di dalam sebuah transaksi pinjaman tidak relevan. Apapun keadaanya, pemberi pinjaman tidak

${ }^{11}$ Khalid Muhammad Ishaque, Islamitation in Pakistan: Analysis Problems and Prospect (Pakistan: Journal an Islamic Banking and Finance, 1984), 91. 
mempunyai hak untuk menerima tambahan atas dan melebihi uang pokok. ${ }^{12}$

Meskipun beberapa Neo-Revivalis utama seperti Mawdudi dan Sayyid Qutb membahas lebih jauh persoalan ketidakadilan dalam riba, secara umum mereka tidak menyatakan bahwa ketidakadilan itu adalah rasion d'etre dari larangan itu. Menurut Mawdudi maksud bahwa dhulm (ketidakadilan) itu merupakan alasan mengapa bunga atas pinjaman itu tidak dibolehkan, tapi dari sini bukan berarti transaksi bunga semacam ini bisa berlangsung jika tidak menyebabkan kekejaman. ${ }^{13}$

Dengan mengikuti jalan pemikiran ini, para penulis Neo-Revivalis menafsirkan riba dengan cara tidak membolehkan setiap tambahan dalam pinjaman. Muwdudi mendefinisakn riba dengan "jumlah yang diterima oleh pemberi pinjaman dari penerima pinjaman dengan angka bunga yang pasti". ${ }^{14}$ Chapra mengatakan bahwa riba mempunyai makna yang sama dengan bunga. ${ }^{15}$ Apapun penilaian dari penafsiran Neo-Revivalis tentang riba, yang jelas penafsiran mereka telah menjadi dasar dari teori dan praktik perbankan Islam sekarang ini.

\section{Analisis Kritis Terhadap Penafsiran Riba Kaum Modern dan Neo- Revivalis}

\section{Kritik terhadap Kaum Modernis}

Sebenarnya term adh'afan mudha'afa yang dijadikan dasar larangan riba hakikatnya hanya menerangkan apa yang telah dipraktikkan oleh orang-orang Arab tidak menerangkan ketentuan bunga (interest) yang dibebankan yang akan tetap dibolehkan jika tidak berlipat ganda. AlQur'an juga menegaskan bahwa setiap tambahan yang melebihi dari nilai pokok yang dipinjam adalah riba yang dilarang (QS. 2:275-278). Aplikasi ini untuk berbagai bunga, apakah bunga itu berlipat ganda atau tidak, bunga tetap maupun berubah-ubah.

\footnotetext{
${ }^{12}$ Ibid., Zahra, Buhuth...99.

${ }^{13}$ Abu al-A'la al-Mawdudi, Probihition of Interest in Islam (Lahore: al-Islam, 1986), 7. Lihat juga Razi, Tafsir, Jus VII. 94.

${ }^{14} \mathrm{Abu}$ al-A'la al-Mawdudi, Towards understanding the Qur'an I (Leicester: Islamic Foundation, 1988), 213

${ }^{15}$ M. Umar Chapra, Towards a Just Monetary System (Leicester: Islamic Foundation, 1985), 57.
} 
Kriteria berlipat ganda dalam ayat itu harus dipahami sebagai hal atau sifat dari riba sama sekali bukan merupakan suatu syarat. Artinya kalau syarat berarti kalau terjadi pelipatgandaan berarti riba, sedangkan kalau tidak berlipat ganda berarti tidak. Sekali lagi itu bukan syarat. Bahkan jika dianalisis secara linguistik maka kata dhi'f itu berarti kelipatan. Sesuatu yang berlipat itu adalah minimal 2 kali lebih besar, sedangkan adh'af adalah bentuk jamak dari kelipatan tadi. Minimal jamak adalah 3, dengan demikian adh'af berarti minimal $2 \times 3=6$. Kalau lipat ganda itu dijadikan syarat, maka sesuai dengan konsekuensi bahasa, minimal harus 6 kali atau berarti bunganya minimal 600\%. Secara operasional dan nalar yang sehat angka tersebut mustahil terjadi di dalam proses perbankan maupun simpan pinjam. Atau secara sederhana jika kita menggunakan logika mafhum mukhalafah, yang berarti jika lipat ganti yang dilarang maka berati yang sedikit tidak boleh, maka kita akan terjadi banyak salah kaprah dalam memahami ayat-ayat Allah. ${ }^{16}$

Mengenai alasan jika darurat (hajah) berarti boleh, maka kita seharusnya melakukan pembahasan komprehensif tentang pengertian darurat itu sendiri. Imam Suyuti menegaskan bahwa darurat adalah "suatu keadaan emergensi, dimana jika seseorang tidak segera melakukan dengan cepat, akan membawanya ke jurang kehancuran atau kematian". Dalam literatur klasik juga sering diungkapkan bahwa darurat itu ibarat orang yang tersesat di hutan dan tidak ada makanan lain kecuali babi, maka dalam keadaan demikian babi itu dibolehkan. Dengan demikan darurat itu punya batasan-batasan yang ketat. Dengan demikian kalau diperhatikan secara seksama, maka kebutuhan masyarakat terhadap pinjaman itu, secara umum jelas belum sampai ada keadaan darurat, baik masa pra-Islam maupun saat ini. ${ }^{17}$

Adapun mengenai pinjaman produktif atau konsumtif, ada data bahwa sebagian besar pinjaman investasi itu digunakan untuk tujuan produksi, sebagaimana umumnya di Hijas (Arab) pada waktu praktik riba dilarang. Thabari juga menerangkan bahwa ada indikasi beberapa suku

\footnotetext{
2002), 56-58

${ }^{16}$ Muhammad Syafi'i Antonio, Bank Syariah dari Teori ke Praktik (Jakarta: Gema Insa Press:

${ }^{17}$ Ibid., 55.
} 
Arab pada saat itu mengunakan uang pinjaman suku lainnya untuk perdagangan dan menanamkan modal.

Mengenai individu atau institusional, maka jika dipandang dari status hukumnya itu adalah sama saja. Semua badan hukum dan pemerintah pada dasarnya merupakan perwakilan dari setiap individu dalam kehidupan bermasyarakat. Setiap institusi juga dapat melakukan eksploitasi sebagaimana pandangan setiap individu dan al-Qur'an tidak membuat perbedaan antara institusi dan individu dalam pesoalan riba.

Sedangkan mengenai bunga nominal atau real maka pada jika mengacu pada perintah al-Quran maka penambahan pada hutang pokok jelas tetap merupakan pelanggaran. Badan ideologi Islam tentang islamisasi perbankan dan lembaga keuangan Pakistan dalam laporannya menyatakan: prinsip dasarnya adalah bahwa kuantitas yang sama harus dikembalikan sebagaimana yang dipinjam, meskipun harga barang itu telah berubah pada waktu itu. ${ }^{18}$

Disamping itu, persoalan mengetahui dengan pasti kurs yang harus diterapkan untuk kompensasi bagi kerugian yang timbul karena inflasi juga merupakan kesulitan tersendiri. Pada kenyataannya ada banyak indeks yang menjadi ukuran daya beli uang, seperti indeks harga konsumen dan indeks harga seluruh penjalan, semua itu adalah akbat dari beberapa kesulitan. Dari sinilah, maka sulit untuk menentukan kurs universal yang bisa digunakan indeksasi. Bahkan jika ditemukan sekalipun, maka kemudahan penggunaanya dalam perbankan juga patut dipertanyakan, karena hal ini berarti bawah bank-bank akan memerlukan untuk mengindekskan depositonya sebagaimana juga pinjamannya pada para penanam modal. Mengindeks yang pertama untuk menghilangkan yang terakhir adalah tidak mungkin dalam perbankan bahkan bisa menimbulkan malapetaka pada laporan keseimbangan bank. Jika penggunaan bunga itu untuk menetralisis, maka hal ini bisa menjadi puncak penggunaan sebuah kejahatan yang lebih besar melawan yang lebih kecil, dan Islam tidak mendorong pengenalan kejahatan-kejahan baru untuk memerangi kejahatan-kejahatan yang sudah ada. Kesempatan untuk

${ }^{18}$ Coucil of slamic Ideology, Consolidatet Recomemendation on the Islamic Economic System (Islamabad: CII, 1983), 12. 
memperoleh bunga nominal, berarti juga dekat pada kreditur. Dari sinilah maka persoalan bunga nominal real menjadi tidak muncul, sehingga setiap bunga seharusnya memang dilarang sebagai riba.

Posisi kaum Modernis sebenarnya bisa juga rusak oleh dua faktor. Pertama, ketidakmampuan mereka untuk menjelaskan sebuah teori yang konsisten tentang riba berdasarkan alasan pelarangan yang ditetapkan dalam al-Qur'an. Kedua, adalah munculnya perbankan Islam yang diilhami oleh pemikiran Neo-Rivivalis mengenai persoalan riba yang memamdang bahwa setiap bunga adalah bunga dan seterusnya berarti dilarang.

2. Kritik terhadap Kaum Neo-Reivalis

Pandangan Neo-Revivalis tentang riba sebagai bunga adalah sebagian besar didasarkan pada penafsiran harfiah terhadap ungkapan alQur'an:

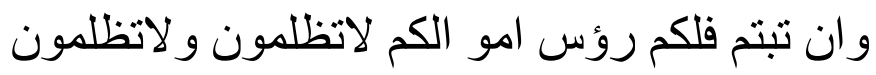

"Jika kamu meminjam, maka kamu berhak untuk menerima uang pokok kamu..."

Dari ayat tersebut Neo-Revivalis menyatakan bahwa tidak ada ruang lingkup untuk membolehkan setiap kenaikan atau melebihi uang pokok pinjaman. Menurut mereka uang pokok itu sama dengan kuantitas tertentu dari suatu uang yang dianggap sah. Padahal istilah ru'usu amwal itu sebenarnya bisa diterjemahkan menjadi uang prinsip. Berdasarkan dari beberapa laporan yang terdapat dalam kitab-kitab tafsir dan juga dalam Sunnah, adalah jelas bahwa uang pokok pada masa Nabi itu adalah berhubungan dengan uang komoditas dalam bentuk emas, perak, hewan, bahan makanan, bahkan alat perang. Emas dan perak dignakan sebagai komoditas tetapi pada waktu yang sama keduanya juga digunakan sebagai komoditas. Uang yang digunakan di Hijas adalah uang komoditas yang digunakan secara luas yang nilainya tentu tergantung pada isi emas atau perak. Masyarakat pra-Islam juga tidak mengenal pembeda uang pokok yang digunakan dalam hutang dan uang yang digunakan secara luas dan 
dianggap sah. Padahal uang komoditas telah diterima sebagai uang yang sah. Dengan demikian bisa saja bahwa dalam dua situasi itu pada akhirnya menyebabkan kebutuhan uang pokok dalam jumlah yang berbeda dari uang yang dianggap sah. Yaitu jika inflasi akan menyebabkan uang pokok dinyatakan dalam jumlah yang lebih besar dari unit uang yang diangggap sah, sedangkan jika deflasi akan menyebabkan uang pokok dinyatakan dalam jumlah yang lebih kecil dari unit uang yang dianggap sah.

Analisis di atas menunjukkan bahwa istilah ru'usu anwal adalah tidak sama dengan nilai numerik mutlak dalam pinjaman uang yang dianggap sah. Artinya uang pokok itu berarti selalu berhubungan dengan sifat dari obyek pinjaman, yaitu bahan pinjaman komoditas akan dipastikan dikembalikan dengan jumlah/nilai komoditas yang dianggap sama. Sementara pinjaman yang akan dinyatakan dalam daya beli uang tersebut terhadap nilai komoditasnya. ${ }^{19}$

Kaum Neo-Revivalis juga terkesan menolak tesis yang menyatakan bahwa pinjaman dalam periode pra-Islam adalah untuk tujuan konsumsi, padahal kenyataannya, rentenir pada saat itu selalu mengembangkan uangnya dari kesengsaraan debitur, dan debitur semakin tenggelam dengan hutangnya, sementara rentenir selalu menuntutnya. Rasanya hal itu tidak akan sering terjadi jika peminjamnya adalah seorang saudagar.

Keadilan yang dibela kaum Neo-Revivalis terkesan hanya muncul untuk satu sisi, dan ini adalah ironis. Mestinya juga harus dilihat bahwa pengusaha saat ini bekerja dalam kondisi yang berbeda dengan pengusaha pada masa awal sejarah Islam. Memang benar bahwa investor itu tidak pasti dalam memperoleh keuntungan dari usaha produksinya, tetapi kenyataannya investor itu baru mau memasuki areal bisnis adalah setelah memperhitungkan untung ruginya. Jia rugi tentu dia tidak akan memasukkan areal bisnis tersebut. Jika yang membuat dia mau masuk dunia bisnis itu adalah setelah yakin bahwa ia tentunya akan memperoleh keuntungan.

Simpati Neo-Revivalis bagi perusahan lemah bagaimanapun tidak biasa diungkapkan ketika yang dirujuk hanyalah nasabah bank Islam. Hukum Islam sendiri tidak secara tegas mengatur urusan pinjaman bagi

${ }^{19}$ Dunya, Taqallubat..., 32-52. 
tujuan-tujuan kemanusiaan. Pinjam (Qard) dalam hukum Islam, hampir tanpa kecuali dianggap sebagai sarana untuk memberikan bantuan bagi orang Islam. Peminjam dipandang sebagai orang yang sangat membutuhkan. Ibnu Ruslan (w.844/1440) mengatakan: pahala qard itu lebih besar dari pada shadaqah, karena tidak seorangpun meminjam itu kecuali ia butuh. Dengan demikian pemberian qard itu dipandang sebagai sebaagai sebuah institusi seperti shadaqah (amal) sehingga ia sangat didorong. Di sisi lain Nabi sendiri mendorong agar kaum muslimin tidak terlibat dalam hutang kecuali sangat membutuhkannya seperti terungkap dalam do'a nama: "Ya Allah saya berlindung kepadaMu dari segala dosa dan hutang". Untuk melepaskan seseorang dari tekanan hutang, Nabi menganjurkan untuk memberikan shadaqoh kepadanya. Bahkan salah satu yang berhak menerima zakat adalah orang yang mempunyai hutang (gharim). Al-Qur'an juga meminta ummat Islam untuk tidak terlalu membebankan debitur dengan meringankan hutangnya, dan mengharap pahala dari Tuhan di akhirat. Semua itu menunjukan bahwa pinjaman adalah sarana utama untuk mengurangi ketertekanan seseorang, dan pinjaman itu benar-benar didorong oleh adanya kebutuhan. Jika seseorang kreditur mau membebaskan beban debitur, berarti ia telah melakukan anjuran al-Qur'an dan al-Hadits.

Sebuah poin menarik adalah bahwa pembayaran hutang, Nabi menganjurkan pengikutnya untuk membayar melebihi hutang itu sendiri. Kenyataannya juga banyak Hadits Nabi yang menyatakan bahwa beliau sendiri juga melakukan hal itu. Beliau bersabda: yang paling baik di antara kamu adalah mereka yang membayar hutangnya dengan cara yang paling baik.

Adalah suatu persoalan jika konsep qard dalam hukum Islam itu dianggap tidak tepat jika hubungan dengan tujuan-tujuan humanis. Karena tidak ada mekanisme yang tepat untuk memberikan pinjaman selain dari tujuan-tujuan humanis, maka masyarakat yang memerlukan pinjaman untuk tujuan humanispun harus mengambil jalan hiyal untuk bisa meminjam, dan inipun dengan rata-rata bunga yang tidak tinggi.

Pembahasan di atas menunjukkan bahwa ada kejanggalan serius dalam pandangan Neo-Revivalis bahwa bunga itu adalah riba. Persoalan 
ini sebenarnya membutuhkan sebuah pandangan baru oleh para ekonom yang memiliki kepedulian, para bankir, ahli keuangan, sosiolog dan tentunya ulama' yang mampu tujuan syariah yang luas dan obyektif. Persoalan penafsiran itu mestinya tidak hanya terkait dengan ulama', karena tidak hanya penafsiran atas sebuah teks kitab suci, tetapi merupakan pesoalan yang mempunyai berbagai cabang dalam areal aktifitas sosial yang luar biasa.

Pada kenyataanya aturan-aturan yang terkait dengan muamalah pada umumnya berhubungan dengan praktik-praktik atau kebiasaan sebuah masyarakat. Dan disinilah aturan-aturan seperti itu bisa diubah sesuai dengan lingkungan yang mengikatnya. Secara lebih khusus ahli hukum dari Anabilah, Tufi (w.716/1316) menyatakan bahwa aturan dalam muamalah itu didasarkan pada kepentingan masyarakat (maslahat alnash). ${ }^{20}$

Bukti-bukti tekstual dan historis juga menegaskan bahwa al-Qur'an dan al-Hadits, tidak melarang perkembangan lembaga-lembaga komersial dan perdagangan. Tidak ada perincian tentang bagaimana bebagai bentuk penjualan dilakukan, juga bentuk-bentuk perdagangan umumnya adalah menunjukkan bahwa al-Qur'an itu memberikan kebebasan yang memadai untuk mengembangkannya dalam bingkai petunjuk dan prinsip-prinsipNya yang luas. Penekanan pada batasan-batasan yang tidak perlu dalam menghadapi perkembangan lembaga-lembaga komersial adalah tidak sejalan dengan perintah al-Qur'an.

Kenyataanya pendapat-pendapat yang diungkapkan oleh para ahli hukum awal tidak bisa menjawab semua masalah perbankan dan keuangan modern. Lembaga-lembaga keuangan dan kontrak-kontrak yang dikembangkan dalam fikih tradisional tidak bisa memberikan jawaban untuk semua masalah komersial dan keuangan kontemporer yang sangat kompleks. Dari sini rasanya perlu untuk melakukan ijtihad atas dasar prinsip dan aturan eksplisit dari al-Qur'an dan al-Hadits, agar ditemukan jalan keluar yang islami.

${ }^{20}$ Najm Al-Din al-Tufi, Risalah al-Tufi Ri 'Ayat al-Maslahat, in Khalaf, Masadir al-Tashri' $f i$ Nas Fihi (Kuwait: Dar al-Qolam, 1872). 
Para sarjana Modernis menyatakan bahwa salah satu ciri khas dari teks dasar utama Islam yaitu al-Qur'an adalah bahwa ia mengandung secara relatif beberapa hukum yang khas, tetapi standartnya tetap mengacu pada sikap dan perilaku. Hal ini merupakan sebuah konsekuensi dari sifat universalitas al-Qur'an dan prinsip Nabi bahwa keluwesan itu harus ada.

\section{Penutup}

Gerakan modernis yang muncul pada paruh kedua abad XIX, lebih menekankan pada pentingnya melakukan penyegaran pemikiran Islam dengan cara membangkitkan kembali gelombang ijtihad dengan meperoleh ide-ide yang relevan dengan al-Qur'an dan al-Hadits. Menurut mereka al-Qur'an merupakan sebuah fenomena yang terdapat dalam lintas sorotan sejarah dan juga melatar-belakangi setting sosial historis tetentu. Dalam memahami fenomena tertentu mereka selalu memperhatikan situasi dan kondisi yang melatarbelakangi munculnya fenomena tersebut. Baik segi moral, agama, maupun setting sosial historisnya dalam menjawab berbagai problematika kehidupan.

Dengan konteks bunga bank seperti yang berlaku pada saat ini dianggap suatu yang wajar. Sementara gerakan Neo-Revivalis yang mulai tumbuh pada paruh pertama abad XX, berusaha untuk mengangkat relevansi ajaran Islam dalam kehidupan masyarakat pada saat ini, serta berusaha menunjukan kekuatan Islam di mata dunia barat. Menurut mereka fungsi ijtihad hanya dilaksanakan terhadap permasalahan yang secara eksplisit tidak disebutkan dalam al-Qur'an maupun al-Hadits. Dengan logika berpikir seperti itu mereka akhirnya mengidentifikasikan bahwa bunga (interest) sebagaimana yang diberlakukan dunia perbankan konvesional adalah termasuk riba. Umat Islam itu harus menerima alQur'an dan al-Hadits itu sebagai aturan yang permanen, serta menerapkanya dalam realitas kehidupan tanpa melakukan perubahan yang disebabkan oleh perbedaan waktu, tempat, keadaan, maupun strata sosial dalam pengembangan ekonomi.

Bagaimanapun juga kehadiran gerakan Modernis dan Neo-Revivalis tersebut benar-benar telah menghisasi bentuk pemikiran Islam dalam lintas 
sejarah modern. Khususnya gerakan Neo-Revivalis, kehadirannya telah berpengaruh besar terhadap teori perkembangan Islam. Teori ini sendiri telah berkembang secara luas ke dalam ruang lingkup perbankan dan keuangan, tentunya dengan penafsiran bahwa bunga (interest) adalah riba.

\section{DAFTAR PUSTAKA}

Al-Jauziyyah, Ibn al-Qayyim. Tt. A'lam al-Muwaqqi' in 'an Rabb al-Alamin II, Dar al-Jil. tt.

Al-Mawdudi, Abu al-A'la. 1986. Probihition of Interest in Islam, Lahore: alIslam.

Al-Mawdudi, Abu al-A'la. 1988. Towards Understanding the Qur'an I, Leicester: Islamic Foundation.

Al-Razi, Al-Imam al-Fahr. 1983. al-Tafsir al-Kabir Juz IV. Kairo: al-Matba'a al-Bahiya.

Al-Sanhuri, Abd. Al-Razzaq. 1967. Masadir al-Haqq fi Figh al-Islam, Beirut: alMajma' al-Arab al-Islam.

Al-Tufi, Najm Al-Din. 1872. Risalah al-Tufi Ri'Ayat al-Maslahat, in Khalaf, Masadir al-Tashri' fi Nas Fihi. Kuwait: Dar al-Qolam.

Antonio, Muhammad Syafi'i. 2002. Bank Syariah dari Teori ke Praktik. Jakarta: Gema Insa Press:.

Assad, Muhammad. 1984. The Massage of The Qur'an, Gibraltar: DarAndalus.

Chapra, M. Umar. 1985. Towards a Just Monetary System. Leicester: Islamic Foundation.

Dunya, Shawqi. 1985. Taqallubat al-Quwwat al-Shar'iyya li al-Nuqud. Kairo: al-Bunuk al-Iskamiyah.

Ideology, Coucil of slamic. 1983. Consolidatet Recomemendation on the Islamic Economic System. Islamabad: CII. 
Ishaque, Khalid Muhammad. 1984. Islamitation in Pakistan: Analysis Problems and Prospect. Pakistan: Journal an Islamic Banking and Finance.

Mallat, Chibli. 1998. The Debate On Riba and interest in twentieth Century Jurisprudence. London: Graham \& Trotman.

Rahman, Fazlur. 1997. Islamic: Challenges and Opportunities. Eidenburgh: Eidenburgh University Press.

Salih, Nabil A. 1986. Unlufun Gain and Legitimate Profil in Islamic Low. Cambridge: Cambridge University Press.

Zahra, Muhammad Abu.1970. Buhuth fi al-Riba, Kuwait: Dar al-Buhuth al‘Ilmiya. 
Jurnal Pendidikan dan Pranata Islam 